Article

\title{
A Landslide Susceptibility Assessment Method Based on GIS Technology and an AHP-Weighted Information Content Method: A Case Study of Southern Anhui, China
}

\author{
Handong He ${ }^{1} \mathbb{D}, \mathrm{Di} \mathrm{Hu}^{2,3, *}$, Qun Sun ${ }^{4}$, Lei Zhu ${ }^{5}$ and Yanrong Liu ${ }^{1}$ \\ 1 School of Resources and Environment, Anhui Agricultural University, Hefei 230036, China; \\ hehandong@ahau.edu.cn (H.H.); liuyanrong@ahau.edu.cn (Y.L.) \\ 2 Key Laboratory of Virtual Geographic Environment, Nanjing Normal University, Ministry of Education, \\ Nanjing 210023, China \\ 3 Jiangsu Center for Collaborative Innovation in Geographical Information Resource Development and \\ Application, Nanjing 210023, China \\ 4 Geological Exploration Technology Institute of Jiangsu Province, Nanjing 210049, China; sunq@jsdky.net \\ 5 School of Economics and Management, Beihang University, Beijing 100191, China; leizhu@buaa.edu.cn \\ * Correspondence: hud316@njnu.edu.cn; Tel.: +86-152-5099-2342
}

Received: 24 April 2019; Accepted: 4 June 2019; Published: 6 June 2019

check for updates

\begin{abstract}
Based on geographic information system (GIS) technology in conjunction with two methods for assessing landslide susceptibility (LS) —namely, a method using experts' knowledge and experience, and a mathematical/statistical method - the LS of southern Anhui, China is assessed using an analytic hierarchy process (AHP) via an AHP-weighted information content method. Landslide-affecting factors are categorized into three main types and 10 subtypes. The values of spatial characteristics of the landslide-affecting factors are obtained using GIS technology. The AHP method is then employed to compare the importance and weights of landslide-affecting factors. The information content method is used to convert the measured values of the landslide-affecting factors in the study area to data reflecting regional stability. The closeness of the relationships between the classification levels of each landslide-affecting factor and landslide occurrence are calculated. The LS of the study area is assessed using the proposed method. The LS assessment shows that high LS, relatively high LS, moderate LS, relatively low LS and low LS regions account for 21.3\%, 20.6\%, 20.1\%, 11.7\% and 26.3\% of the study area, respectively. Finally, the accuracy of the LS assessment results is analyzed using two methods: the assessment, including an analysis of random landslide sites for the validating models; and the area below a receiver operating characteristic (ROC) curve of area under curve (AUC) value. The results show that the proportion of landslide sites in the regions of each LS level determined using the AHP-weighted information content method increases as the LS level increases, and that the accuracies of the AHP-weighted information content method were $8.1 \%$ and $5.7 \%$ higher than those of the AHP method and information content method, respectively.
\end{abstract}

Keywords: LS assessment; LS level; AHP-weighted information content method; landslide-affecting factors; geographic information system

\section{Introduction}

In geomorphology, a "landslide" is the movement of a mass of rock, debris or earth down a slope under the influence of gravity [1-3]. To study landslides using geographic information system (GIS), it is first necessary to identify landslides based on their characteristics as deep-seated, including 
main scarps, debris, mounds and hollows, or shallow landslides. Shallow landslides are composed of scar, flow and deposit parts [4-6]. Landslides, one of the main types of natural disasters, gravely threaten and harm people's lives, property and environments. Data show that from January 2004 to December 2016, a total of 55,997 people were killed in 4862 separate non-seismic landslide events around the world. The spatial distribution of landslides varies, with Asia representing the dominant geographical area [7]. Landslide assessment [8-10] is of great importance for the prediction [11] and targeted prevention and control of landslides. Landslide assessments include susceptibility, hazard and risk assessments. Susceptibility assessments are the basis [12-14] for hazard and risk assessments. Susceptibility refers to the spatial possibility of occurrence of landslides of a specific type and volume. Hazard assessments determine the possibility of occurrence of a specific landslide in a given region within a certain period of time. A risk assessment adds relevant information from the relevant disaster-affected bodies, including their temporal and spatial probabilities, vulnerability and numbers (casualties and economic losses). Therefore, a landslide susceptibility (LS) assessment of a given area is the basis for a landslide assessment of the area.

Currently, there are two main types of LS assessment methods: assessments based on expert knowledge and experience [15,16], and mathematical and statistical methods [17,18]. Methods based on expert knowledge and experience use qualitatively determined LS based on experts' knowledge of landslides, and such methods include the geological and geomorphological analysis method [19], the factor analysis method [20], the fuzzy comprehensive evaluation method [21-23] and the analytic hierarchy process (AHP) method [24-26]. The geological and geomorphological analysis method comprehensively determines and qualitatively assesses the LS of the study area based on a combination of geological and geomorphological parameters of landslide formation obtained from field surveys. The factor analysis method selects landslide-affecting factors based on experts' knowledge and experience, and assigns weights to these factors based on their importance in determining an LS assessment index. The fuzzy comprehensive evaluation and AHP methods are both based on the expert rating method. Using the AHP method, multiple hazards (landslide, flood, seismic hazards, etc.) must account for the uncertainty in the weighting coefficients [27-29]. The ratings are established based on the classification of assessment indices. Weights are assigned to landslide-affecting factors by means of membership, and on this basis the LS is assessed. Methods based on expert knowledge and experience methods are, to a certain extent, subjective, and all methods require a rating based on experts' knowledge and experience. Ratings by different experts often lead to different assessment results.

Mathematical and statistical analysis methods assume that there is no correlation between affecting factors. These methods perform statistical analysis primarily based on the available geological data for landslides, quantitatively assess various classifications of each landslide-affecting factor based on data and establish a correlation between the landslide-affecting factors of each classification and landslide formation $[30,31]$. The main mathematical and statistical analysis methods include the information content method [32-34], the weight of evidence method [35,36], the logistic regression method [37-39] and the multivariate linear regression method [40-42]. The information content method calculates the spatial characteristics of each landslide-affecting factor based on the information content representing the LS level, and uses these characteristics to measure the closeness of the relationship between a factor and landslide occurrence. The weight of evidence method calculates the posteriori probability based on available landslide records and, on that basis, determines which regions of the study area are susceptible to landslides, assessing LS using overlay analysis of relevant topographic information regarding landslides. The logistic regression and multivariate linear regression methods determine the probability of landslide occurrence by determining quantitative correlations between landslide-affecting factors and constructing a regression model. Other models, such as machine learning algorithms [43] —including the random forest (RF), boosted regression tree (BRT), classification and regression tree (CART) and general linear (GLM) models-have been applied in earth sciences. RF is a model-building strategy that provides estimators of the Bayes classifier [44]. Using RFs, the influence of sensitivity and scaling issues in LS mapping can be studied, while indicating the unit (scale) and training 
process, which strongly influence classification accuracy and the prediction process [45]. This study presents an LS assessment method based on geographic information system (GIS) technology combined with an AHP-weighted information content method. This method combines the advantages of expert knowledge and experience with mathematical and statistical analysis.

\section{Methodology}

\subsection{Information for the Study Area}

The study area, southern Anhui, is prone to frequent landslides. Situated in eastern mainland China $\left(29^{\circ} 31^{\prime}-31^{\circ} \mathrm{N}, 116^{\circ} 31^{\prime}-119^{\circ} 45^{\prime} \mathrm{E}\right)$, the study area is under the jurisdiction of Anhui Province and encompasses a total area of $36,536 \mathrm{~km}^{2}$. Records show that 707 landslides have occurred in the study area in recent years. Landslide development in the study area is primarily controlled by such basic factors as geological structure, terrain and landforms and hydrometeorological conditions. Located within the Yangtze stratigraphic region, the study area has a complex geological structure with residual Neoarchean and Paleoproterozoic formations composing the deep crust, and primarily Mesoproterozoic metamorphic rock sequences as basement. Faults within the study area are mostly northeast-trending and nearly east-west-trending, which has a significant controlling effect on geomorphic and geological conditions. With complex terrain and landform conditions, the study area is home to high mountains, deep valleys and steep slopes, as well as a wide distribution of phyllite, sandy shale and granite bedrock that has undergone severe weathering. Topographically, the study area gradually increases in elevation from north to south. There are plains in the northern part of southern Anhui along the Yangtze River. However, mountains and hills account for more than $70 \%$ of the total area of southern Anhui. There are three mountain ranges within the study area that extend from southwest to northeast, including the Jiuhua, Huangshan and Tianmu ranges. A large number of basins and valleys, mostly approximately $200 \mathrm{~m}$ and a few below $100 \mathrm{~m}$ in elevation, are distributed between these three parallel mountain ranges. Due to its hydrometeorological conditions, the study area is prone to landslides. Additionally, the study area has a mild subtropical monsoon climate with a wide annual range of temperatures, moderate precipitation, abundant sunshine, a long frost-free season and prevailing easterlies. The water systems in southern Anhui are part of the Yangtze River Basin, which form a dense, water-rich network. As a result of the geological structure, terrain and landform and hydrological conditions, landslides in the study area are zonally distributed, spatially concentrated and uneven. There is a low landslide distribution density in alluvial valley plains and hilly regions below $200 \mathrm{~m}$ in elevation. Landslides in regions above $400 \mathrm{~m}$ but below $800 \mathrm{~m}$ in elevation in the Jiuhua, Huangshan and Tianmu Ranges are zonally distributed along concentrated fault zones. Landslides are concentrated and occur in groups in regions characterized by relatively soft rocks (e.g., phyllite and sandy shale).

LS data were extracted from the List of Potential Small-Scale Geological Disaster Sites in Anhui Province, which is published by the public Geological Survey and Environmental Monitoring Center of Anhui Province. Shallow landslides composed of scars, flows and deposits were used in this paper, as shown in Figure 1.

There are a total of 707 landslide sites in southern Anhui, as shown in Figure 2. Of these sites, 495 were used in training modelling, and 212 were used to validate the accuracy of the model. The information for the factors was obtained using the following GIS spatial analysis-based methods. Geological structure data (i.e., formation lithology and fault data) were obtained by vectorizing a 1:250,000 geological map. Additionally, $30 \mathrm{~m}$ digital elevation model (DEM) data from the United States Geological Survey (USGS) were used as terrain and landform data. Topographic elevation, slope, aspect and curvature data were extracted directly from DEM data. Vector data for first- and second-order streams extracted from a 1:50,000 topographic map were used as hydrological data, as shown in Table 1. 


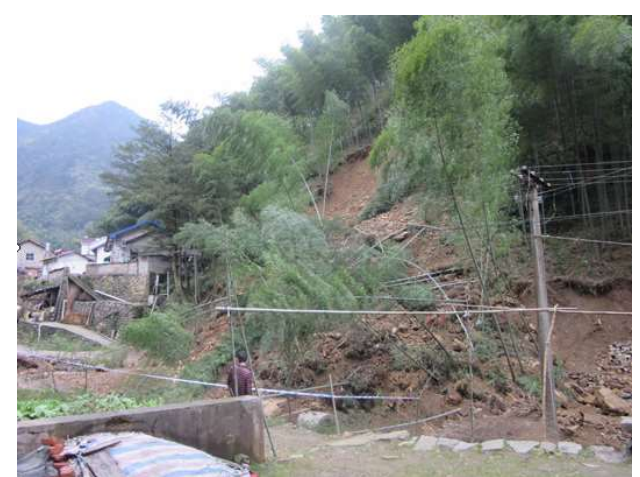

(a)

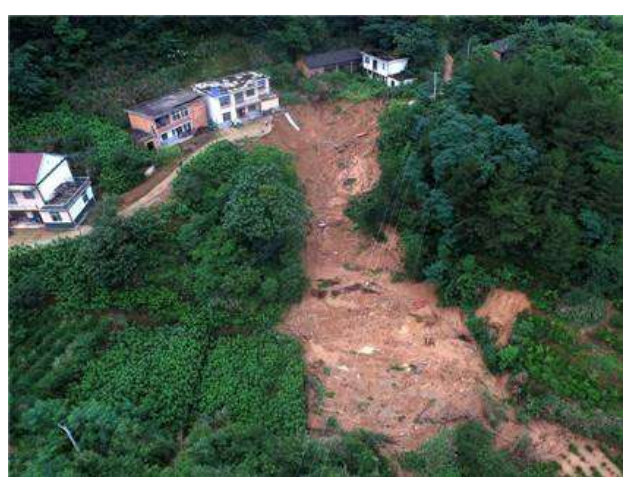

(b)

Figure 1. Examples of landslide types in southern Anhui, China: (a) landslide in Xuanzhou county, (b) landslide in Yuexi county.

Table 1. Research data introduction.

\begin{tabular}{|c|c|c|}
\hline Landslide Factor & Origin Website & Description \\
\hline (a) Lithology & http://geocloud.cgs.gov.cn & The hardness of Rocks \\
\hline (b) Distance from faults & http://geocloud.cgs.gov.cn & Buffer range of faults \\
\hline (c) NDVI & http://www.resdc.cn & Normalized difference vegetation index \\
\hline (d) Elevation & https://www.usgs.gov & $30 \mathrm{~m}$ digital elevation model \\
\hline (e) Slope & https://www.usgs.gov & Extracted from digital elevation model (DEM) \\
\hline (f) Aspect & https://www.usgs.gov & Extracted from digital elevation model (DEM) \\
\hline (g) Profile curvature & https://www.usgs.gov & Extracted from digital elevation model (DEM) \\
\hline (h) Distance from rivers & http://www.resdc.cn & Buffer range of rivers \\
\hline (i) Annual rainfall & http://www.resdc.cn & $\begin{array}{l}\text { Interpolation based on } 2400 \text { stations in China } \\
\text { (2000-2015) by ANUSPLIN package which is } \\
\text { to provide a facility for transparent analysis } \\
\text { and interpolation of noisy multi-variate data } \\
\text { using thin plate smoothing splines. }\end{array}$ \\
\hline (j) Distance from roads & $\begin{array}{c}\text { https: } \\
\text { //www.openstreetmap.org }\end{array}$ & Buffer range of first grade roads \\
\hline Landslide Sites & Origin Website & Description \\
\hline Shallow landslide & $\begin{array}{l}\text { http://ags.org.cn/ } \\
\text { http://ahdzhj.com/ }\end{array}$ & $\begin{array}{l}\text { Derived from field measurement and } \\
\text { interprets the satellite images }\end{array}$ \\
\hline
\end{tabular}

In this study, by overlaying each landslide-affecting factor layer and the landslide site layer, the attribute values of the landslide sites in the factor layer were determined. On this basis, the landslide-affecting factors were classified (i.e., reclassified). The information content of each classification factor was calculated and correlated to various levels of the corresponding thematic map. The results generated by each thematic map were subjected to an overlay analysis based on the weight of each factor in the AHP model. The AHP-weighted information content was calculated by summing the product of the correlation weight of each landslide-affecting factor and its classification information content. By classifying the calculation results, an LS distribution map based on the weighted information content model was obtained. Finally, 212 landslide sites were used to examine the accuracy of the model. The landslide locations were then randomly divided into a ratio of 70/30 for the training and validation models. 


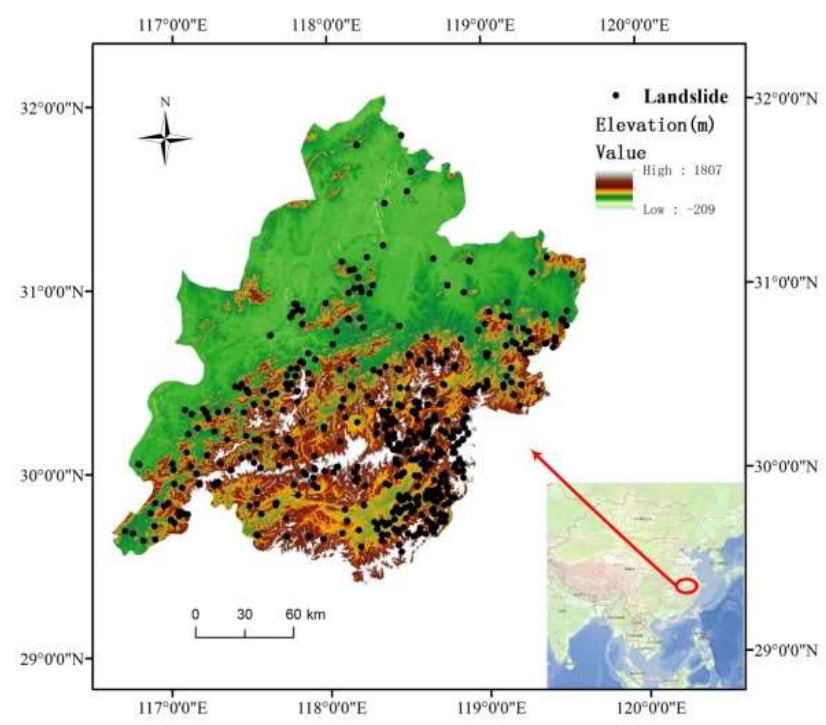

(a)

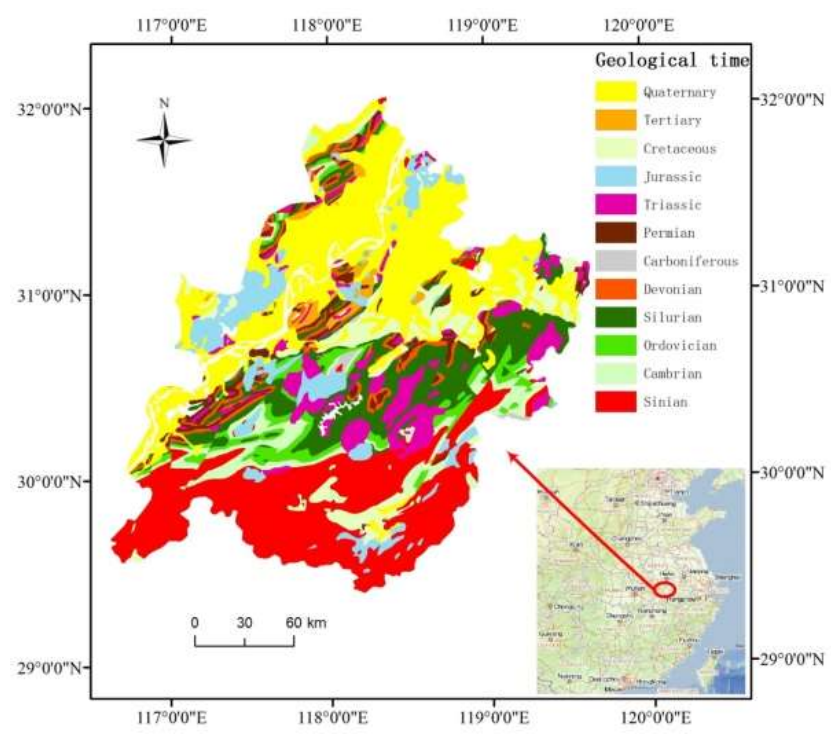

(b)

Figure 2. Distribution of landslide sites in southern Anhui, China: (a) elevation map based on a $30 \mathrm{~m}$ digital elevation model (DEM) from shuttle radar topography mission (STRM), (b) geologic map of the distribution of rocks of different ages.

\subsection{AHP-Weighted Information Content Method}

In an LS assessment, the study area is divided into several types of homogenous regions, which are then ranked based on LS. The key to an LS assessment lies in the possible landslide-affecting factors [46-48]. Therefore, the selection of landslide-affecting factors is particularly important. The occurrence of a landslide is the result of the combined action of multiple types of factors. Overall, these factors can be categorized into two types: internal factors (e.g., geologic structural factors, terrain and landform factors and hydrological factors) and external factors (e.g., inducing factors such as rainfall, earthquakes and roads). This study considers LS to be caused by internal factors and anthropogenic factors. Specifically, the following four types (including 10 subtypes) of factors are considered: geology and structure (both lithology and distance from faults), terrain and landforms (including normalized difference vegetation index (NDVI), elevation, slope, aspect and 
profile curvature), hydrometeorological conditions (both distance from rivers and annual rainfall) and anthropogenic factors (distance from roads).

This study proposes a method for calculating AHP-weighted information content. In this method, the information content model is improved using the AHP method. The AHP-weighted information content is calculated by summing the product of the correlation weight of each landslide-affecting factor and its classification information content. The equation for this method is as follows:

$$
L=\beta 1 G 1+\beta 2 G 2+\beta 3 G 3+\beta 4 G 4+\beta 5 G 5+\beta 6 G 6+\beta 7 G 7+\beta 8 G 8+\beta 9 G 9+\beta 10 G 10
$$

In Equation (1), $\boldsymbol{\beta 1} \mathbf{\beta 1} \boldsymbol{\beta 1 0}$ are the respective weights of the 10 landslide-affecting factors (lithology, distance from faults, NDVI, elevation, slope, aspect, profile curvature, distance from rivers, annual rainfall and distance from roads) determined using the AHP model method; G1-G10 are the raster layers obtained using the GIS reclassification method, which is used to reclassify the spatial levels of susceptibility caused by the landslide-affecting factors that are determined using the information content model method; and $\mathbf{L}$ is the LS level of the region. Figure 3 shows the classification of LS obtained by the spatial overlay of the GIS raster data.

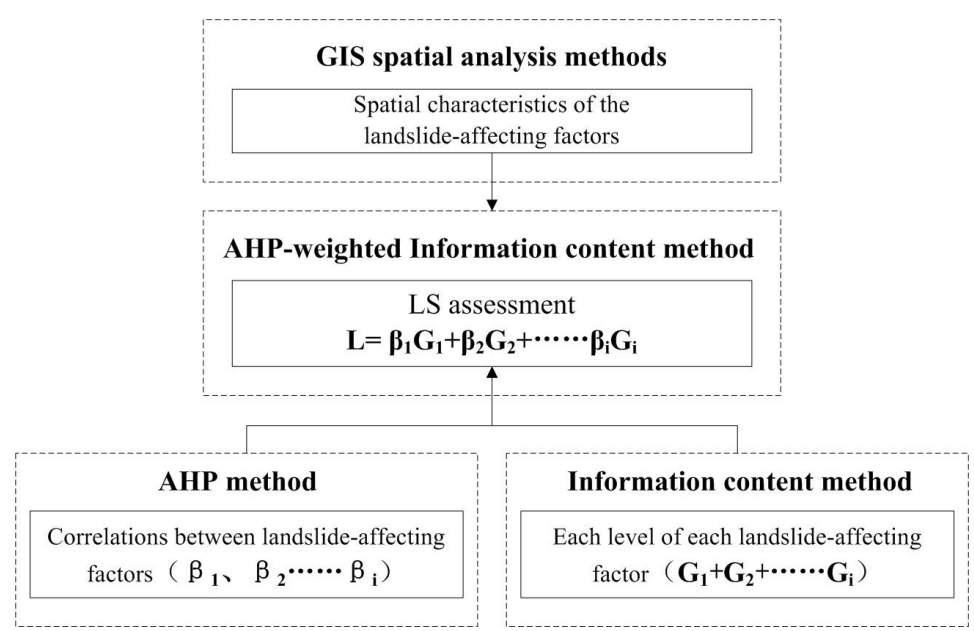

Figure 3. Landslide susceptibility (LS) assessment based on geographic information system (GIS) and the analytic hierarchy process (AHP)-weighted information content method.

In this study, the importance of the landslide-affecting factors is determined by comparing any two factors using the AHP method, which is based on certain criteria, and then quantitatively calculated based on a predefined scale. A judgement matrix is formed with the results. On this basis, the weight of each landslide-affecting factor is calculated. Based on the actual conditions in the regions where landslides have occurred, the measured values (i.e., the parameters of the landslide-affecting factors) are converted to information contents that reflect regional stability. The closeness of the relationships between the classification level of each landslide-affecting factor and landslide occurrence is assessed by calculating the information content provided by the factor to the landslide event. When assessing LS, the information content method defines the landslide as the study object. Some landslide-affecting factors such as faults, lithology, elevation, slope and aspect are the assessment indices of the model. Relevant regional LS is predicted and classified based on the information contents contributed by these landslide-affecting factors and their comprehensive levels.

Whether or not a landslide will occur is related to the amount and quality of information on disaster-causing factors and is determined based on information contents. The theoretical model for calculating information contents is as follows:

$$
\mathrm{I}\left(\mathrm{Y}, \mathrm{x}_{1} \mathrm{x}_{2} \mathrm{x}_{3} \cdots \mathrm{x}_{\mathrm{n}}\right)=\ln \frac{\mathrm{P}\left(\mathrm{Y}, \mathrm{x}_{1} \mathrm{x}_{2} \mathrm{x}_{3} \cdots \mathrm{x}_{\mathrm{n}}\right)}{\mathrm{P}(\mathrm{Y})} .
$$


In Equation (2), $\mathrm{I}\left(\mathrm{Y}, \mathrm{x}_{1} \mathrm{x}_{2} \mathrm{x}_{3} \cdots \mathrm{x}_{\mathrm{n}}\right)$ is the information content provided by the combination of the disaster-causing factors $\mathrm{x}_{1}, \mathrm{x}_{2}, \mathrm{x}_{3}, \cdots, \mathrm{x}_{\mathrm{n}} ; \mathrm{P}\left(\mathrm{Y}, \mathrm{x}_{1} \mathrm{x}_{2} \mathrm{x}_{3} \cdots \mathrm{x}_{\mathrm{n}}\right)$ is the probability of landslide occurrence under the combined action of the disaster-causing factors $\mathrm{x}_{1}, \mathrm{x}_{2}, \mathrm{x}_{3}, \cdots, \mathrm{x}_{\mathrm{n}}$; and $\mathrm{P}(\mathrm{Y})$ is the probability of landslide occurrence.

In this study, feasible calculation equations supported by the disaster-causing factor samples are used as substitutes in the calculation. Based on the landslide conditions in the study area, Equations (4)-(6) are used to calculate and comprehensively analyze the information contents of the landslide-affecting factors.

The information content provided by each factor to the landslide event $\mathrm{K}$ is calculated as follows:

$$
\mathrm{I}\left(\mathrm{x}_{\mathrm{i}}, \mathrm{H}\right)=\ln \frac{\mathrm{P}\left(\mathrm{x}_{\mathrm{i}} / \mathrm{H}\right)}{\mathrm{P}\left(\mathrm{x}_{\mathrm{i}}\right)},
$$

where $\mathrm{P}\left(\mathrm{x}_{\mathrm{i}} / \mathrm{H}\right)$ is the probability of occurrence of $\mathrm{x}_{\mathrm{i}}$ under the landslide distribution conditions and $\mathrm{P}\left(\mathrm{x}_{\mathrm{i}}\right)$ is the probability of occurrence of $\mathrm{x}_{\mathrm{i}}$ in the study area.

In practice, frequency can be used to estimate probability as follows:

$$
\mathrm{I}\left(\mathrm{x}_{\mathrm{i}}, \mathrm{H}\right)=\ln \frac{\mathrm{N}_{\mathrm{i}} / \mathrm{N}}{\mathrm{S}_{\mathrm{i}} / \mathrm{S}}
$$

where $\mathrm{S}$ is the total area of the study area; $\mathrm{N}$ is the total area of landslides in the study area; $\mathrm{S}_{\mathrm{i}}$ is the number of disaster-causing factors $x_{i}$ present in the study area; and $\mathrm{N}_{\mathrm{i}}$ is the number of landslides distributed within a certain disaster-causing factor $x_{i}$. The goal of the model is to calculate the relative distribution density $\frac{N_{\mathrm{i}} / \mathrm{N}}{\mathrm{S}_{\mathrm{i}} / \mathrm{S}}$ of each type of landslide in each disaster-causing factor layer, following

$$
\sum_{\mathrm{i}=1} \mathrm{I}\left(\mathrm{x}_{\mathrm{i}}, \mathrm{H}\right)=\sum_{\mathrm{i}=1} \ln \frac{\mathrm{N}_{\mathrm{i}} / \mathrm{N}}{\mathrm{S}_{\mathrm{i}} / \mathrm{S}}
$$

where the total information content Ii is used as the comprehensive index that measures the effects of the factor on landslide occurrence. The higher Ii, the more easily landslides can occur.

$\mathrm{G}_{\mathrm{i}}$ is the reclassification of rasters of the landslide-affecting factors. Based on Ii, five LS levels are ultimately determined for each landslide-affecting factor, including high, relatively high, moderate, relatively low and low LS levels. A map showing the LS levels associated with each landslide-affecting factor is ultimately obtained using the GIS raster data reclassification method.

In this study, the effects of 10 factors (i.e., lithology, distance from faults, NDVI, elevation, slope, aspect, profile curvature, distance from rivers, annual rainfall and distance from roads) on landslide formation in the study area are analyzed using a GIS-based spatial analysis method. The study area is ultimately divided into five types of regions based on weighted information contents using the proposed calculation equations. These include high LS, relatively high LS, moderate LS, relatively low LS and low LS regions, thereby achieving an assessment of LS and division of the study area based on LS level.

\subsection{Preparation of the AHP-Weighted Information Content Method}

\subsubsection{AHP Method}

The occurrence of landslides is comprehensively affected by geological structure, terrain and landform, as well as hydrometeorological conditions. Thus, the LS of the study area was assessed using 10 affecting factors (i.e., lithology, distance from faults, NDVI, elevation, slope, aspect, profile curvature, distance from rivers, annual rainfall and distance from roads). The weight of each assessment factor was determined using the AHP method after establishing an assessment index system. Based on the actual conditions in the study area combined with expert experience, a judgement matrix was constructed for the landslide-affecting factors in the study area, as shown in Table 2, which summarizes 
the normalized weights. The matrix $(\lambda \max =0.703$; consistency index $(\mathrm{CI})=0.089$; random index $(\mathrm{RI})$ $=1.48$; consistency ratio $(\mathrm{CR})=0.57<1$ ) passed the consistency check.

Table 2. AHP judgement matrix of the landslide-affecting factors.

\begin{tabular}{|c|c|c|c|c|c|c|c|c|c|c|c|}
\hline & P1 & P2 & P3 & P4 & P5 & P6 & P7 & P8 & P9 & P10 & Weight \\
\hline P1 & 1 & 4 & 3 & 4 & 2 & 5 & 4 & 2 & 3 & 2 & 0.2143 \\
\hline P2 & $1 / 4$ & 1 & $1 / 2$ & 2 & $1 / 5$ & 3 & 1 & $1 / 3$ & $1 / 2$ & 1 & 0.0558 \\
\hline P3 & $1 / 3$ & 2 & 1 & 2 & $1 / 5$ & 3 & $1 / 2$ & $1 / 3$ & $1 / 2$ & $1 / 3$ & 0.0573 \\
\hline $\mathrm{P} 4$ & $1 / 4$ & $1 / 2$ & $1 / 2$ & 1 & $1 / 4$ & 3 & $1 / 3$ & $1 / 3$ & $1 / 3$ & $1 / 3$ & 0.0364 \\
\hline P5 & $1 / 2$ & 5 & 5 & 4 & 1 & 6 & 4 & 2 & 3 & 3 & 0.2101 \\
\hline P6 & $1 / 5$ & $1 / 3$ & $1 / 3$ & $1 / 3$ & $1 / 6$ & 1 & $1 / 4$ & $1 / 2$ & $1 / 4$ & $1 / 4$ & 0.0262 \\
\hline P7 & $1 / 4$ & 1 & $1 / 2$ & 3 & $1 / 4$ & 4 & 1 & $1 / 4$ & $1 / 2$ & $1 / 4$ & 0.0565 \\
\hline P8 & $1 / 2$ & 3 & 3 & 3 & $1 / 2$ & 2 & 4 & 1 & $1 / 2$ & $1 / 2$ & 0.1083 \\
\hline P9 & $1 / 3$ & 2 & 2 & 3 & $1 / 3$ & 4 & 2 & 2 & 1 & 3 & 0.1226 \\
\hline P10 & $1 / 2$ & 1 & 3 & 3 & $1 / 3$ & 4 & 4 & 2 & $1 / 3$ & 1 & 0.1126 \\
\hline \multicolumn{4}{|c|}{ P1 = lithology } & \multicolumn{4}{|c|}{ P2 = Distance from faults } & \multicolumn{4}{|c|}{ P3 = NDVI } \\
\hline \multicolumn{4}{|c|}{ P4 = Elevation } & \multicolumn{4}{|c|}{ P5 = Slope } & \multicolumn{4}{|c|}{ P6 $=$ Aspect } \\
\hline \multicolumn{4}{|c|}{ P7 = Profile curvature } & \multicolumn{4}{|c|}{ P8 = Distance from rivers } & \multicolumn{4}{|c|}{ P9 = Annual rainfall } \\
\hline \multicolumn{4}{|c|}{ P10 = Distance from roads } & \multicolumn{8}{|c|}{$\mathrm{CR}=0.57<1$} \\
\hline
\end{tabular}

\subsubsection{Information Content Method}

In an LS assessment, the measured values of the factors reflecting regional stability are often converted to information contents, which are then used as quantitative indices for LS-based division. The involved calculation principle is as follows. The information prediction viewpoint states that the amount and quality of information obtained in the geological disaster prediction process is correlated with the actual conditions of the occurrence of the geological disaster; that is, information content can be used to assess and predict geological disasters. Based on the distribution characteristics and formation conditions of landslides in southern Anhui, as well as relatively extensively used assessment indices, the 10 landslide-affecting factors are reclassified. Figure 4 shows the classification of the landslide-affecting factors.

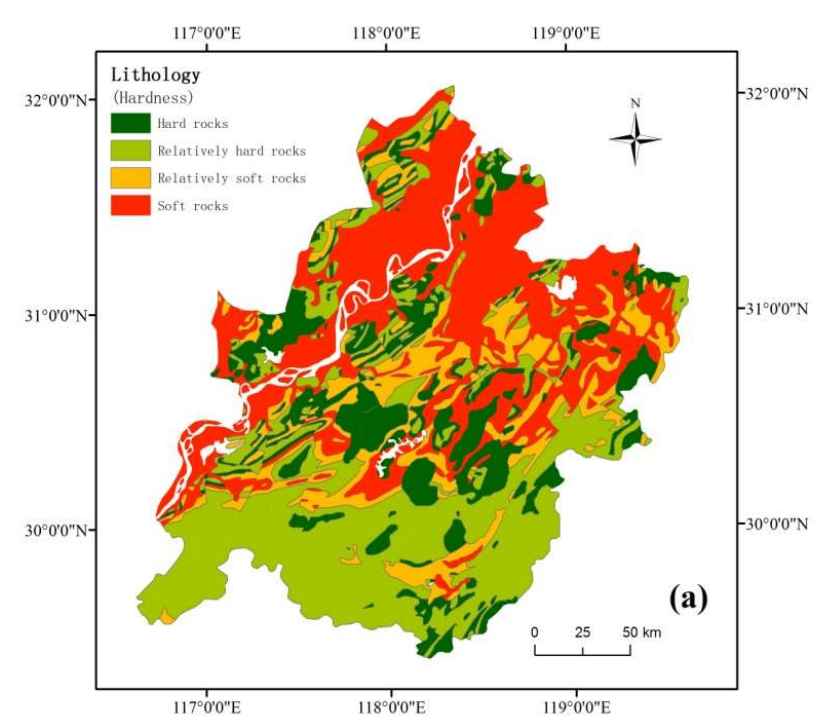

Figure 4. Cont. 

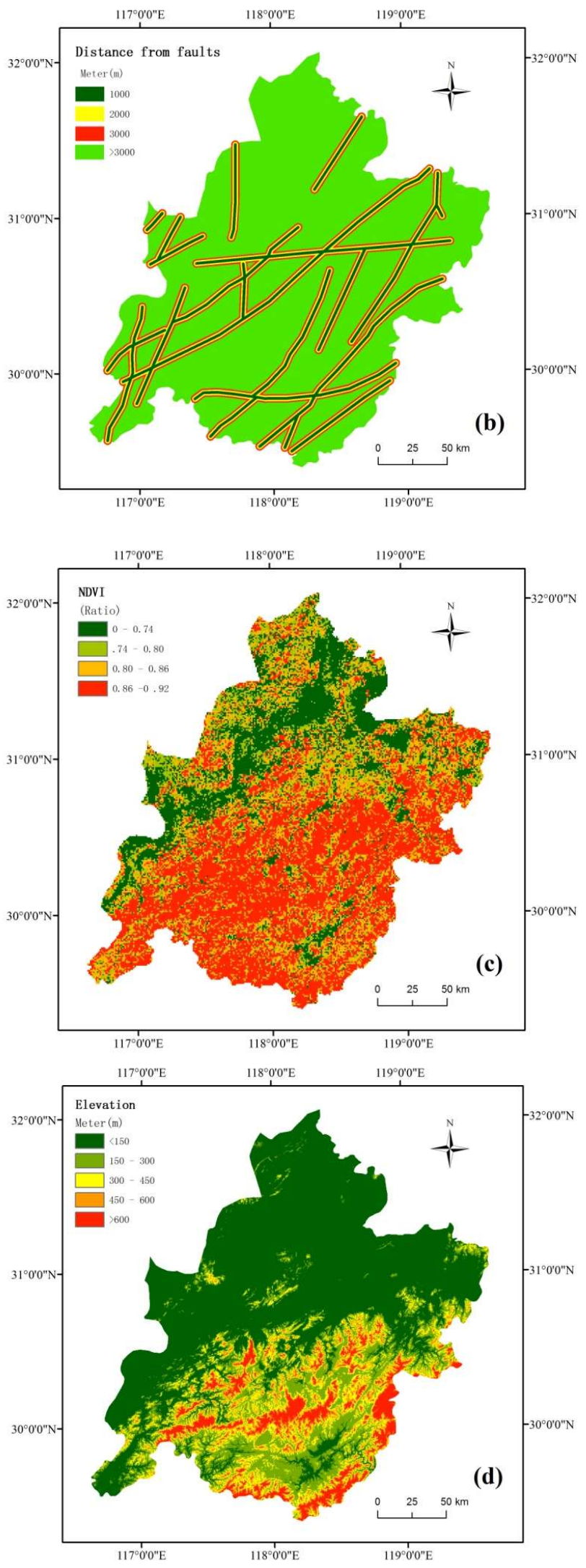

Figure 4. Cont. 

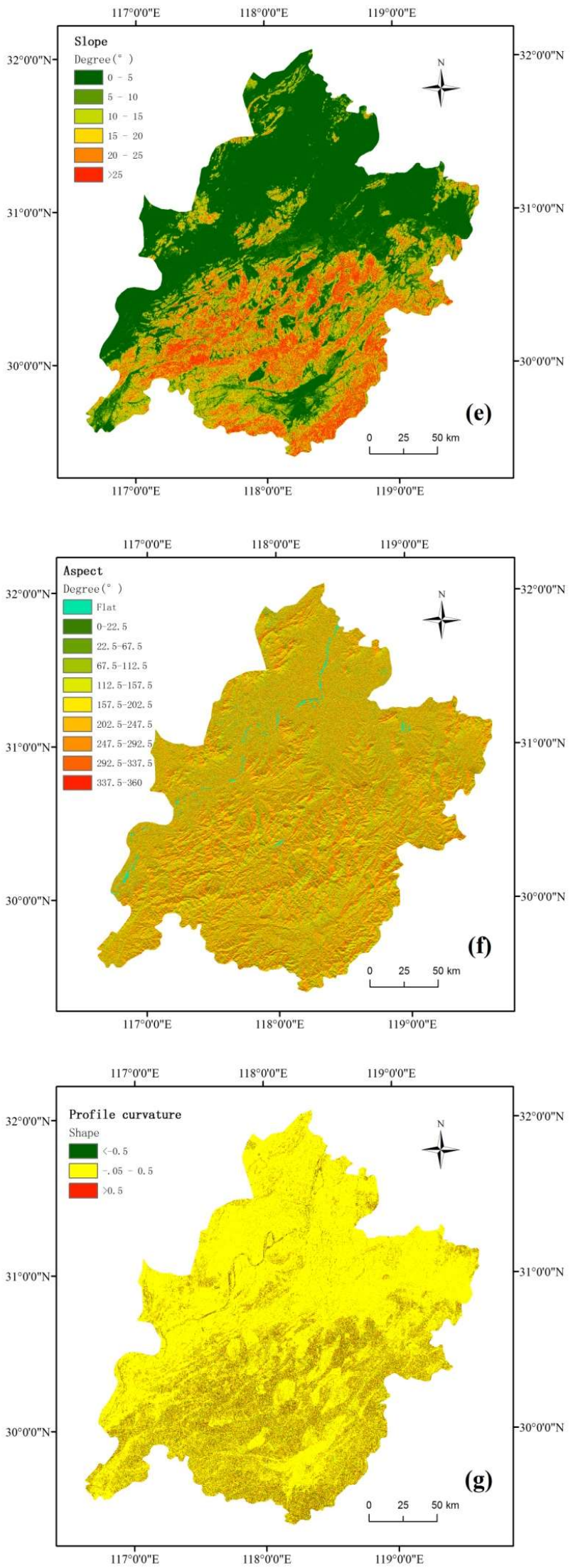

Figure 4. Cont. 

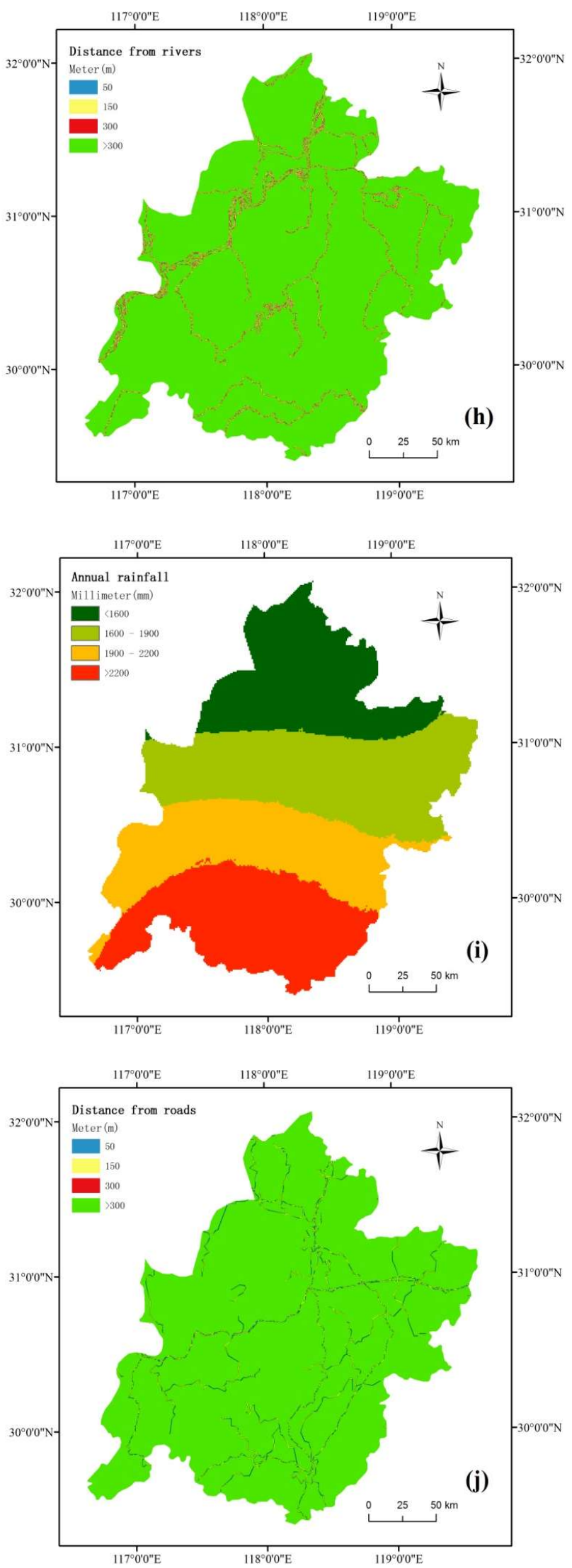

Figure 4. Classification of information contents of the landslide-affecting factors: (a) lithology, (b) distance from faults, (c) NDVI, (d) elevation, (e) slope, (f) aspect, (g) profile curvature, (h) distance from rivers, (i) annual rainfall, (j) distance from roads. 
The 10 landslide-affecting factors are classified as follows:

(a) Lithology. Formation lithologies are classified into four types: hard, relatively hard, relatively soft and soft rocks.

(b) Distance from faults. Four buffer zones are created at distances of $<1000,1000-2000,2000-3000$ and $>3000 \mathrm{~m}$ from the fault zone.

(c) NDVI. NDVI is classified into four ranges: $<0.74,0.74-0.80,0.80-0.86$ and $0.86-0.92$.

(d) Elevation. Elevations are categorized into five ranges: <150, 150-300, 300-450, 450-600 and $>600 \mathrm{~m}$.

(e) Slope. Slopes are categorized into six ranges: $0^{\circ}-5^{\circ}, 5^{\circ}-10^{\circ}, 10^{\circ}-15^{\circ}, 15^{\circ}-20^{\circ}, 20^{\circ}-25^{\circ}$ and $>25^{\circ}$. Convex slopes are prone to rock falls and many landslides caused by earthquakes, while concave slopes are prone to debris slides or flows along the valleys [49].

(f) Aspect. Aspects are categorized into eight types: east, west, south, north, southeast, southwest, northeast and northwest.

(g) Profile curvature. Profile curvatures are categorized into three types: convex slopes (profile curvature $>0.5$ ), concave slopes (profile curvature $<-0.5)$ and linear slopes $(-0.5<$ profile curvature $<0.5)$.

(h) Distance from rivers. Four types of buffer zones are created at distances of $<50,50-150,150-300$ and $>300 \mathrm{~m}$ from the river.

(i) Annual rainfall. Annual rainfall is categorized into four ranges: $<1600,1600-1900,1900-2200$ and $>2200 \mathrm{~mm}$.

(j) Distance from roads. Four types of buffer zones are created at distances of $<50,50-150,150-300$ and $>300 \mathrm{~m}$ from the road.

\subsubsection{AHP-Weighted Information Content Method}

Landslides are primarily controlled by the four main factors (i.e., geological structure, terrain and landforms, hydrometeorological conditions and anthropogenic factors). The 10 landslide-affecting factors (i.e., lithology, distance from faults, NDVI, elevation, slope, aspect, profile curvature, distance from rivers, annual rainfall and distance from roads) are classified into 46 levels using the GIS reclassification function. Table 3 summarizes the number of landslides distributed within a certain disaster-causing factor $(\mathrm{Ni})$ in the study area, the number of landslides distributed within a certain disaster-causing factor to total ratio $(\mathrm{Ni} / \mathrm{N})$, the area of landslides distributed within a certain disaster-causing factor to total ratio (Si/S), information content (I), weight, weighted information content for each level of each landslide-affecting factor and Rank.

The calculated information contents show that, in the information contents for the 46 assessment factors calculated in this study, the maximum and minimum AHP-weighted information contents are 0.3901 and -0.5661 , respectively. Landslide development is concentrated in the relatively soft and hard rock regions of southern Anhui. There is a relatively high probability of landslide occurrence within $2 \mathrm{~km}$ of faults. There is a relatively high probability of landslide occurrence when NDVI is high. Elevation and slope have a notable controlling effect on landslide formation. Landslides mainly occur in regions with an elevation of $150-450 \mathrm{~m}$ and a slope of $5^{\circ}-20^{\circ}$. There is a relatively high probability of landslide occurrence on concave slopes. The probability of landslide occurrence is within $1 \mathrm{~km}$ of a body of water. Precipitation also has a relatively notable controlling effect on landslide formation. Landslides mainly occur in regions with annual rainfall greater than $1900 \mathrm{~mm}$. The probability of landslide occurrence is highest within $150 \mathrm{~m}$ of a body of water. 
Table 3. Calculation of the AHP-weighted information contents of the landslide-affecting factors.

\begin{tabular}{|c|c|c|c|c|c|c|c|c|c|}
\hline Landslide Factor & $\begin{array}{c}\text { Property of } \\
\text { Factor }\end{array}$ & Level & $\mathrm{Ni}$ & $\mathrm{Ni} / \mathrm{N}$ & $\mathrm{Si} / \mathrm{S}$ & I & Weight & $\begin{array}{l}\text { Weighted } \\
\text { Information } \\
\text { Content }\end{array}$ & Rank \\
\hline \multirow{3}{*}{ (a) Lithology } & \multirow{3}{*}{ Hardness } & Hard rocks & 26 & 0.0525 & 0.0920 & -0.5605 & 0.2143 & -0.1201 & 44 \\
\hline & & Relatively soft rocks & 228 & 0.4606 & 0.3038 & 0.4162 & 0.2143 & 0.0892 & 10 \\
\hline & & Soft rocks & 12 & 0.0242 & 0.3403 & -2.6417 & 0.2143 & -0.5661 & 46 \\
\hline \multirow{3}{*}{$\begin{array}{l}\text { (b) Distance from } \\
\text { faults }\end{array}$} & \multirow{3}{*}{ Meter (m) } & $0-1000$ & 36 & 0.0727 & 0.0835 & -0.1381 & 0.0558 & -0.0077 & 29 \\
\hline & & $2000-3000$ & 21 & 0.0424 & 0.0822 & -0.6614 & 0.0558 & -0.0369 & 36 \\
\hline & & $>3000$ & 403 & 0.8141 & 0.7514 & 0.0802 & 0.0558 & 0.0045 & 20 \\
\hline \multirow{4}{*}{ (c) NDVI } & \multirow{4}{*}{ Ratio } & $0-0.74$ & 57 & 0.1152 & 0.2250 & -0.6699 & 0.0573 & -0.0384 & 37 \\
\hline & & $0.74-0.80$ & 78 & 0.1576 & 0.1458 & 0.0777 & 0.0573 & 0.0045 & 21 \\
\hline & & $0.80-0.86$ & 162 & 0.3273 & 0.2193 & 0.4004 & 0.0573 & 0.0229 & 16 \\
\hline & & $0.86-0.92$ & 195 & 0.3939 & 0.4099 & -0.0397 & 0.0573 & -0.0023 & 27 \\
\hline (d) Elevation & Meter (m) & $>600$ & 5 & 0.0101 & 0.0628 & -1.8279 & 0.0364 & -0.0665 & 41 \\
\hline \multirow{6}{*}{ (e) Slope } & \multirow{6}{*}{ Degree $\left({ }^{\circ}\right)$} & $0-5$ & 143 & 0.2889 & 0.4487 & -0.4403 & 0.2101 & -0.0925 & 43 \\
\hline & & $5-10$ & 125 & 0.2525 & 0.1476 & 0.5367 & 0.2101 & 0.1128 & 7 \\
\hline & & $10-15$ & 104 & 0.2101 & 0.1009 & 0.7334 & 0.2101 & 0.1541 & 5 \\
\hline & & $15-20$ & 71 & 0.1434 & 0.0941 & 0.4213 & 0.2101 & 0.0885 & 11 \\
\hline & & $20-25$ & 33 & 0.0667 & 0.0854 & -0.2475 & 0.2101 & -0.0520 & 40 \\
\hline & & $>25$ & 16 & 0.0323 & 0.1232 & -1.3382 & 0.2101 & -0.2812 & 45 \\
\hline \multirow{3}{*}{ (f) Aspect } & \multirow{3}{*}{ Degree $\left(^{\circ}\right)$} & $337.5-22.5$ & 60 & 0.1212 & 0.1220 & -0.0061 & 0.0262 & -0.0002 & 26 \\
\hline & & $22.5-67.5$ & 38 & 0.0768 & 0.1170 & -0.4218 & 0.0262 & -0.0111 & 31 \\
\hline & & $67.5-112.5$ & 48 & 0.0970 & 0.1248 & -0.2520 & 0.0262 & -0.0066 & 28 \\
\hline \multirow{4}{*}{$\begin{array}{l}\text { (h) Distance from } \\
\text { rivers }\end{array}$} & \multirow{4}{*}{ Meter (m) } & $0-50$ & 38 & 0.0768 & 0.0074 & 2.3388 & 0.1083 & 0.2533 & 3 \\
\hline & & $50-150$ & 19 & 0.0384 & 0.0148 & 0.9559 & 0.1083 & 0.1035 & 8 \\
\hline & & $150-300$ & 22 & 0.0444 & 0.0216 & 0.7207 & 0.1083 & 0.0781 & 12 \\
\hline & & $>300$ & 413 & 0.8343 & 0.9562 & -0.1363 & 0.1083 & -0.0148 & 34 \\
\hline \multirow{4}{*}{ (i) Annual rainfall } & \multirow{4}{*}{$\begin{array}{l}\text { Millimeter } \\
(\mathrm{mm})\end{array}$} & $0-1600$ & 11 & 0.0222 & 0.0244 & -0.0935 & 0.1226 & -0.0115 & 32 \\
\hline & & $1600-1900$ & 88 & 0.1778 & 0.2435 & -0.3146 & 0.1226 & -0.0386 & 38 \\
\hline & & $1900-2200$ & 258 & 0.5212 & 0.4688 & 0.1060 & 0.1226 & 0.0130 & 17 \\
\hline & & $>2200$ & 135 & 0.2727 & 0.2633 & 0.0352 & 0.1226 & 0.0043 & 22 \\
\hline \multirow{4}{*}{$\begin{array}{l}\text { (j) Distance from } \\
\text { roads }\end{array}$} & \multirow{4}{*}{ Meter (m) } & $0-50$ & 102 & 0.2061 & 0.0064 & 3.4644 & 0.1126 & 0.3901 & 1 \\
\hline & & $50-150$ & 76 & 0.1535 & 0.0126 & 2.4965 & 0.1126 & 0.2811 & 2 \\
\hline & & $150-300$ & 85 & 0.1717 & 0.0183 & 2.2403 & 0.1126 & 0.2523 & 4 \\
\hline & & $>300$ & 229 & 0.4626 & 0.9626 & -0.7327 & 0.1126 & -0.0825 & 42 \\
\hline
\end{tabular}

\section{Results}

The weighted information contents of the 10 landslide-affecting factors (i.e., lithology, distance from faults, NDVI, elevation, slope, aspect, profile curvature, distance from rivers, annual rainfall and distance from roads) are the assessment indices for the LS-based division. The LS assessment of southern Anhui was obtained based on the information contents and weights in Table 3 using the following equation:

$$
\begin{gathered}
\mathrm{L}=\sum \beta_{\mathrm{i}} \times \mathrm{G}_{\mathrm{ij}}=0.2143 \times \mathrm{G}_{1 j}+0.0558 \times \mathrm{G}_{2 \mathrm{j}}+0.0573 \times \mathrm{G}_{3 \mathrm{j}}+0.0364 \times \mathrm{G}_{4 \mathrm{j}}+ \\
0.2101 \times \mathrm{G}_{5 \mathrm{j}}+0.0262 \times \mathrm{G}_{6 \mathrm{j}}+0.0565 \times \mathrm{G}_{7 \mathrm{j}}+0.1083 \times \mathrm{G}_{8 \mathrm{j}}+0.1226 \times \mathrm{G}_{9 j}+0.1126 \times \mathrm{G}_{10 \mathrm{j}}
\end{gathered}
$$

where $\mathrm{L}$ is the weighted information content of the landslide-affecting factors for southern Anhui; $\beta_{i}$ is the AHP weight of the ith landslide-affecting factor; and $G_{i j}$ is the information content of the classification attribute $\mathrm{j}$ of the ith landslide-affecting factor (where $\mathrm{I}=1,2,3,4,5,6,7,8,9$ and 10 , 
respectively correspond to lithology, distance from faults, NDVI, elevation, slope, aspect, profile curvature, distance from rivers and annual rainfall).

With the weighted information content-based LS assessment model for southern Anhui, the information content of each single factor layer was multiplied by its weight (obtained using the AHP analysis method), then the single factor layers with the weighted information contents were overlain using the ArcGIS raster calculator tool, thereby generating an overlain weighted information content map for landslides, as shown in Figure 5.

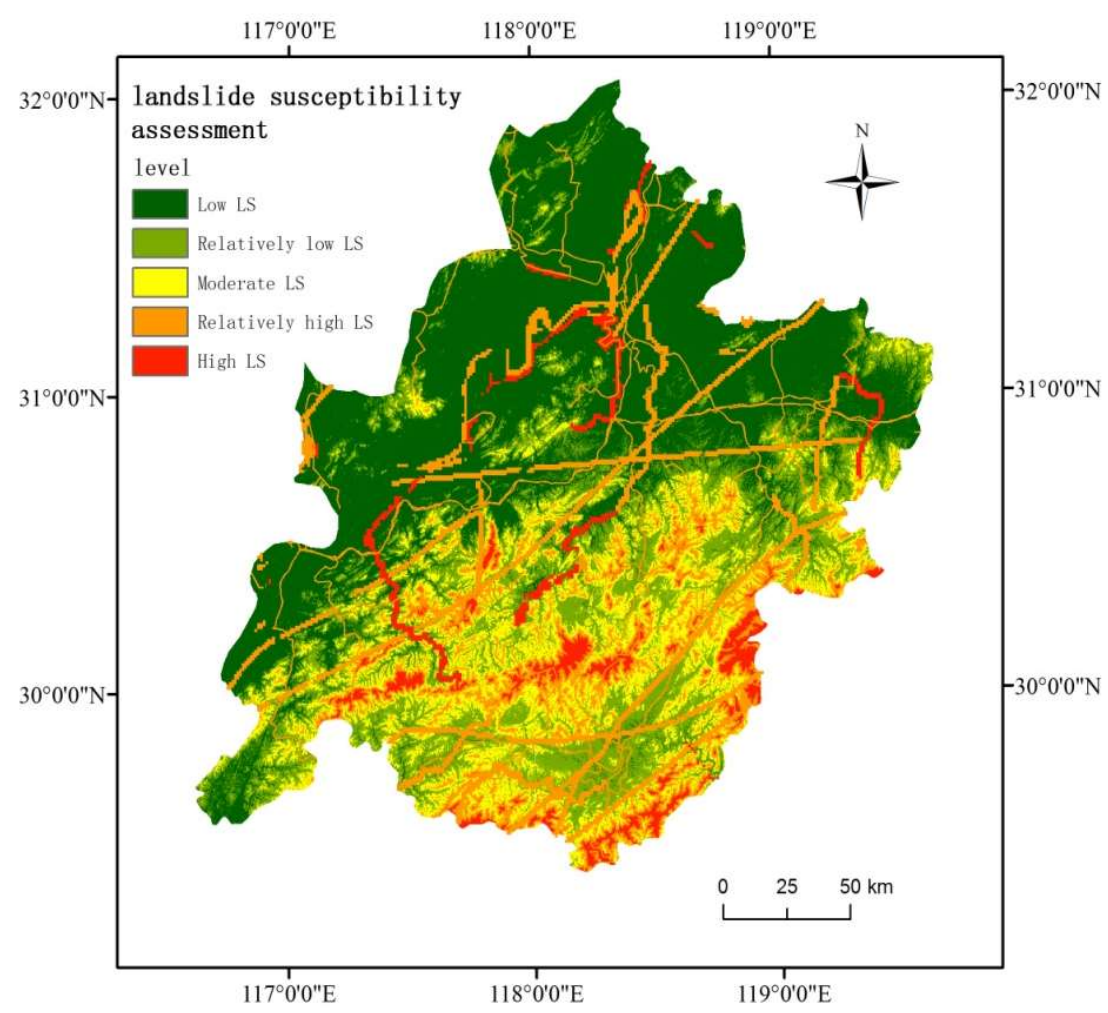

Figure 5. LS assessment of the study area based on GIS spatial analysis and the AHP-weighted information content method.

Here, the natural breaks method, which is commonly used in mathematical statistics, is employed to reclassify the weighted information content map for landslides in southern Anhui. The LS of the study area is categorized into five levels: low LS $(-0.635,-0.376)$; relatively low LS $(-0.376,-0.131)$; moderate LS (-0.131, 0.059); relatively high LS $(0.059,0.237)$; and high LS $(0.237,0.476)$.

Based on the landslide susceptibility assessment map for southern Anhui (Figure 4), the proportions of regions of southern Anhui with various LS levels (low LS; relatively low LS; moderate LS; relatively high LS; and high LS) can be determined using the GIS-based spatial statistical function, the results of which are as follows: high LS regions account for $21.3 \%$; relatively high LS regions account for $20.6 \%$; moderate LS regions account for $20.1 \%$; relatively low LS regions account for $11.7 \%$; and low LS regions account for $26.3 \%$.

Following Table 2 and in conjunction with the list of weighted information contents for landslide sites in southern Anhui (Table 3), the characteristics of the relatively high LS and high LS regions of southern Anhui are determined by the following:

(a) Lithology: Formation lithology is the material basis for landslide formation and activity. Landslides within a certain region occur within a certain formation. Rock type and hardness affect slope stability and difficulty of surface erosion, and are two of the most important landslide-affecting factors and internal conditions for landslide formation. Landslides vary 
significantly between formations that differ in geologic age and lithology. Landslides in southern Anhui mostly occur in regions characterized by relatively soft rock.

(b) Distance from faults: Structural fault zones, which develop on weak structural planes, contain fragmented rocks and are central locations for landslide occurrences. Small faults often become a controlling factor for landslide boundaries. In terms of the overall trend, landslides in southern Anhui are controlled by faults. The farther a region is from a fault, the lower its landslide density. Landslide numbers and area densities are significantly higher in regions within $2 \mathrm{~km}$ of a fault than in other regions.

(c) NDVI: In a region with high vegetation coverage, soil erosion does not occur easily, terrain erosion is slow and the damage to slopes is relatively insignificant. Generally, NDVI is an important index that reflects vegetation cover. The higher the NDVI, the higher the vegetation growth. The probability of landslide occurrence in southern Anhui is relatively high in regions with a high NDVI (0.80-0.86).

(d) Elevation: Elevation reflects the terrain in a small region. However, landslides are significantly affected by elevation. Clearly, landslides in southern Anhui are mainly concentrated within an elevation range of 150-450 m.

(e) Slope: Slope is an important factor that affects landslide development and directly affects slope stability. The landslides occur depending on the type of landslide and the materials of the slopes, as well as on triggers such as rainfall. As a slope increases, the shear stress on the slope increases, and the probability of landslide occurrence also increases. In southern Anhui, landslides are concentrated in regions with slopes of $5^{\circ}-25^{\circ}$, and the rate of landslide occurrence in regions with slopes of $5^{\circ}-15^{\circ}$ is the highest, suggesting that regions with slopes of $5^{\circ}-15^{\circ}$ are favorable for landslide occurrence in southern Anhui.

(f) Aspect: Slopes with different aspects differ in solar radiation intensity, which affects a multitude of factors, including temperature difference, evaporation capacity, vegetation cover and slope surface, as well as slope and landslide stability. Aspects that favor landslide occurrence in the study area are $157.5^{\circ}-202.5^{\circ}$ and $247.5^{\circ}-292.5^{\circ}$.

(g) Profile curvature: Profile curvature is categorized into three types-convex slopes (profile curvature $>0.5)$, concave slopes (profile curvature $<-0.5)$ and linear slopes $(-0.5<$ profile curvature $<0.5$ ). In contrast, precipitation can easily accumulate on a concave slope, which will soften the soil. Concave slopes in southern Anhui are the most prone to landslides.

(h) Distance from rivers: Rivers stress the conditions of landslide masses and alter their previous stable state, which may allow landslides to occur more easily. Landslides are active in regions where scouring intensity is enhanced as a result of hydrostatic action or human disturbance. In southern Anhui, there is a high probability of landslide occurrence in regions within 0-50 $\mathrm{m}$ of a river.

(i) Annual rainfall: Precipitation is the most important landslide-inducing factor in southern Anhui. Heavy-precipitation storms and persistent rainfall can both induce landslides. In regions with loose soil, rainwater infiltrates the slopes, thereby inducing landslides. In southern Anhui, there is a relatively high probability of landslide occurrence in regions with annual rainfall greater than $1900 \mathrm{~mm}$.

(j) Distance from roads: It is obvious that the artificial and natural parts of slopes around roads are more sensitive to landslide manifestation [29]. In southern Anhui, there is a high probability of landsliding in regions within $0-150 \mathrm{~m}$ of a road.

\section{Discussion}

The accuracy of the LS assessment results for the study area was comparatively analyzed using two methods: the 30\% random landslide site for the validation models and the area under a receiver operating characteristic (ROC) curve (AUC). 


\subsection{Random Landslide Site for the Validating Models Assessment and Analysis}

Based on the landslide susceptibility assessment results, 212 random landslide sites were introduced as validation data, and the proportions of random landslide sites in regions of each LS level were calculated using the AHP-weighted information content method, the AHP method and the information content method, respectively (as shown in Figure 6).

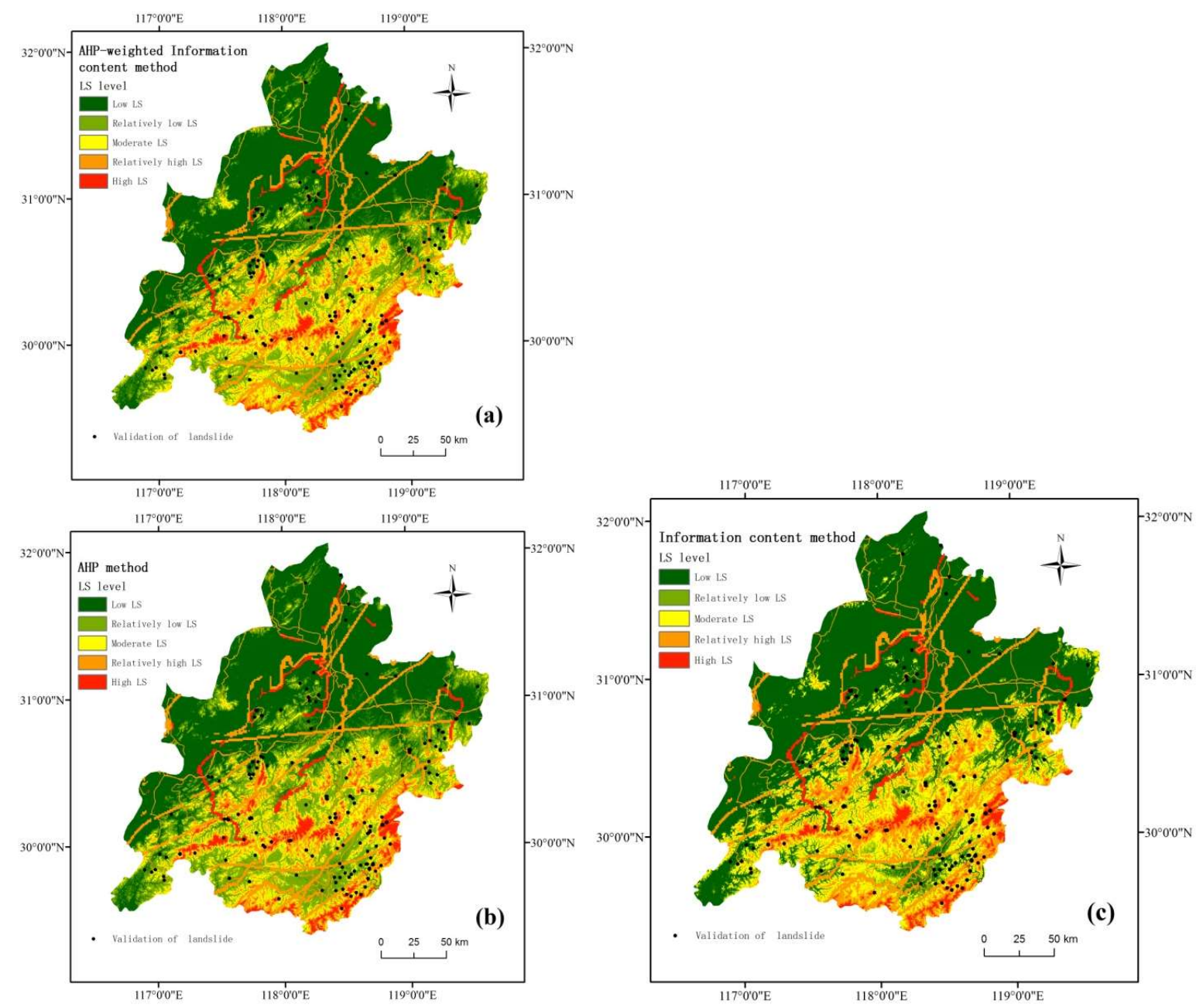

Figure 6. Validation of LS assessment of 212 randomly selected landslide sites for the validation models.

(a) AHP-weighted information content method, (b) AHP method, (c) information content method.

A comparison of the LS assessment results and the distribution of random landslide sites in the study area shows that all of the LS assessment results correspond well to the distribution of landslide sites (as showed in Table 4). However, as demonstrated in Figure 7, the proportion of landslide sites in the regions of each LS level determined using the AHP-weighted information content method increases as the LS level increases, showing a notable linear correlation. This suggests that the LS levels determined by the AHP-weighted information content method agree with the actual occurrence of landslides and that the assessment results are relatively reliable. 
Table 4. Comparison of the proportions of landslide sites determined using the three methods.

\begin{tabular}{cccc}
\hline LS Level & $\begin{array}{c}\text { AHP-Weighted Information } \\
\text { Content Method }\end{array}$ & $\begin{array}{c}\text { AHP } \\
\text { Method }\end{array}$ & $\begin{array}{c}\text { Information Content } \\
\text { Method }\end{array}$ \\
\hline Low LS regions & $2 \%$ & $2 \%$ & $2 \%$ \\
Relatively low LS regions & $4 \%$ & $4 \%$ & $4 \%$ \\
Moderate LS regions & $18 \%$ & $24 \%$ & $22 \%$ \\
Relatively high LS regions & $24 \%$ & $19 \%$ & $20 \%$ \\
High LS regions & $52 \%$ & $51 \%$ & $52 \%$ \\
\hline
\end{tabular}

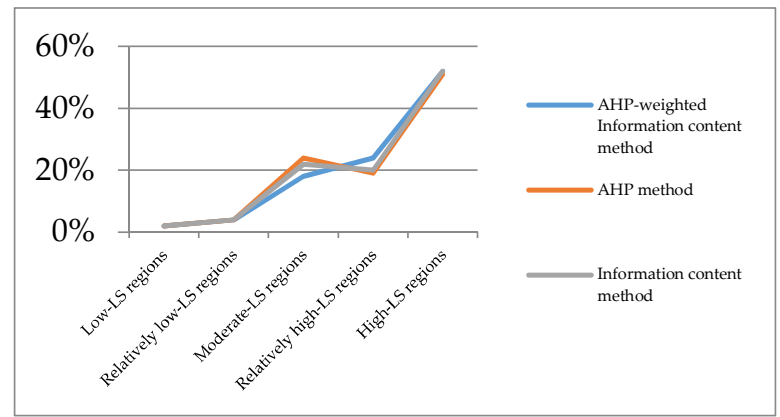

Figure 7. Analysis of the proportion of landslide sites in regions of different LS levels determined using the three methods.

\subsection{AUC-Based Comparative Analysis}

The performances of landslide assessments according to the three evaluation methods are shown in Table 5. The AHP-weighted information content method indicates the highest performance for classification of landslide areas (sensitivity $=75.94 \%$ ), followed by the information content method (sensitivity $=75.49 \%$ ) and the AHP method (sensitivity $=74.75 \%$ ). For the classification of non-landslide areas, the highest performance is from the AHP-weighted information content method (specificity $=75.94 \%$ ), followed by the information content method (specificity $=73.64 \%$ ) and the AHP method (specificity $=71.68 \%$ ). In general, all of the methods performed well in the classification of both landslide and non-landslide areas.

Table 5. Model performance of the three methods.

\begin{tabular}{cccc}
\hline Parameters & $\begin{array}{c}\text { AHP-Weighted Information } \\
\text { Content Method }\end{array}$ & AHP Method & $\begin{array}{c}\text { Information Content } \\
\text { Method }\end{array}$ \\
\hline True positive & 161 & 148 & 154 \\
\hline True negative & 161 & 162 & 162 \\
\hline False positive & 51 & 64 & 58 \\
\hline False negative & 51 & 50 & 0.7549 \\
\hline Sensitivity (\%) & 0.7594 & 0.7475 & 0.7364 \\
\hline Specificity (\%) & 0.7594 & $\begin{array}{c}\text { Specificity (\%) }=\text { True negative/(True } \\
\text { negative + False positive) }\end{array}$ \\
\hline Sensitivity $(\%)=$ True positive/(True positive + \\
False negative)
\end{tabular}

The general performance of landslide methods using the ROC curve method $[50,51]$ is shown in Figure 8. All landslide models performed well in the LS assessment (AUC > 0.8). Of the methods, the AHP-weighted information content method showed the highest performance (AUC $=0.893$ ), followed by the information content method (AUC $=0.842$ ) and the AHP method (AUC $=0.821)$, respectively. The three methods all produced relatively good assessment results. The accuracy of the AHP-weighted information content method was $8.1 \%$ and $5.7 \%$ higher than those of the AHP and information content 
methods, respectively, indicating that the proposed AHP-weighted information content method can produce better LS assessment results for the study area compared to the conventional AHP and information content methods.

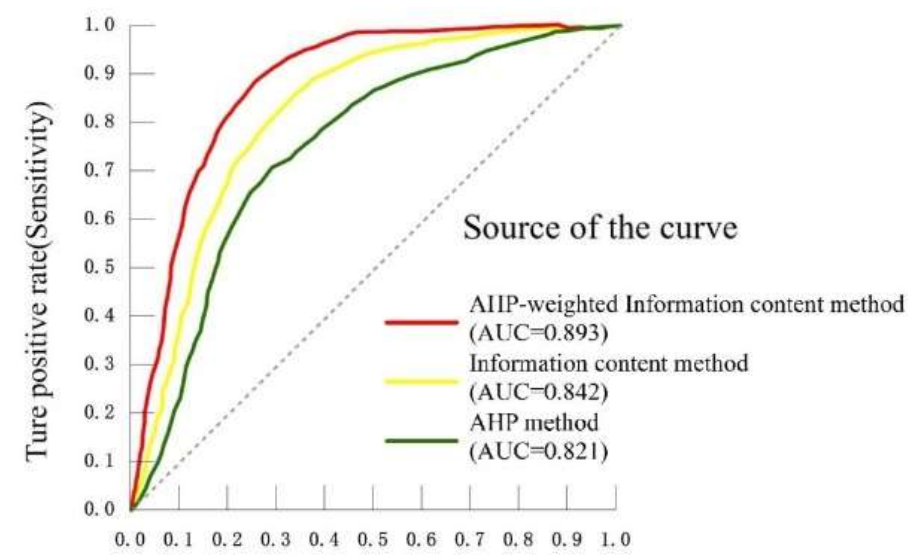

Figure 8. Receiver operating characteristic (ROC)-based comparison of the LS assessment results and analysis of area under curve (AUC) data.

Hence, methods based on expert knowledge and experience, as well as mathematical and statistical analysis, both have advantages and disadvantages in assessing LS [50-52]. Methods based on expert knowledge and experience can determine the correlations between landslide-affecting factors and the relationship between each landslide-affecting factor and landslide occurrence based on the knowledge of geological experts and their experience with landslides. However, expert judgements are predominantly non-qualitative and empirical, thereby affecting the objectivity of the assessment results and rendering the assessment results unverifiable.

Mathematical and statistical analysis methods quantitatively calculate the relationship between each single landslide-affecting factor and landslide occurrence based on geological and environmental data for landslides, thereby avoiding a subjective assignment of weights to the assessment indices. However, these methods overlook the complexity of geological causes of regional landslides and fail to satisfactorily describe the correlations between a number of landslide-affecting factors. The key to landslide susceptibility assessment lies in the correlations and relationships between landslide-affecting factors and LS level. Expert knowledge and experience can be used to assign a relatively satisfactory weight to each factor. However, due to a lack of data and numerical calculations, models constructed using methods based on expert knowledge and experience have low objectivity and universality. Mathematical and statistical analysis can reflect the values of the indices of each single factor at each classification level, but fail to consider the importance of each factor and the relationships between factors. As a result, there is a lack of understanding of the relationships between landslide-affecting factors in geological knowledge.

To overcome the deficiencies in the methods based on expert knowledge and experience and mathematical and statistical analysis methods used in current landslide research, some researchers have attempted to combine these two types of methods [53-57] by assessing LS using mathematical and statistical methods coupled with data calculation methods based on expert experience with landslides. However, LS assessment is a complex process and requires a comprehensive consideration of various factors. Combining methods based on expert knowledge and experience and mathematical and statistical analysis methods still faces some challenges, including (1) how to obtain the spatial characteristics of each landslide-affecting factor and calculate the difference between spatial characteristics at each classification level via GIS [58-60]; (2) how to determine the correlations between landslide-affecting factors and assign a weight to each landslide-affecting factor from the formation mechanism of landslides based on expert knowledge and experience; and (3) how to calculate the correlations between the numerical indices of each level of each landslide-affecting factor with the LS 
level from the specific conditions surrounding the occurrence of a landslide using mathematical and statistical methods [31]. In view of these problems, this study presents an LS assessment method based on GIS technology combined with an AHP-weighted information content method. First, the spatial characteristics of each classification level of each landslide-affecting factor are calculated using the GIS spatial analysis method. Second, the correlation weight between landslide formation and each landslide-affecting factor is qualitatively calculated using the AHP method based on expert knowledge and experience. Third, the information content method is employed to quantitatively correlate the LS level with the numerical indices of each factor at each classification level from mathematical and statistical perspectives. Finally, by constructing an AHP-weighted information content method, the weight of each AHP factor is combined, relatively satisfactorily, with the numerical indices of each information content factor at each classification level. This method combines the advantages of expert knowledge and experience with mathematical and statistical analysis. Additionally, the LS of southern Anhui was also assessed, and the results were used to examine the applicability of the proposed method based on the AHP-weighted information content method to an assessment of LS.

\section{Conclusions}

The LS assessment results obtained using the AHP-weighted information content method agree well with actual landslide observations. The actual proportion of landslides in a region increases linearly with the LS level (low LS; relatively low LS; moderate LS; relatively high LS; and high LS) of the region and, theoretically, conforms to the classification principle.

To establish an assessment index system, a weighted information content method is used to determine each classification parameter of the model. The AHP method, which is used to obtain weighting coefficients, is combined with the information content method. The resultant method combines qualitative analysis and quantitative calculations. Based on the AUC values, the accuracy of the AHP-weighted information content method is $8.1 \%$ and $5.7 \%$ higher than those of the AHP and information content methods, respectively. As a result, the AHP-weighted information content method produces more reliable LS assessment results.

The GIS spatial analysis method is used to process and calculate 46 levels of spatial data for the 10 landslide-affecting factors in southern Anhui and their weighted information contents. Because of its advantages regarding data analysis, GIS spatial analysis can rapidly and accurately store and display spatial data and mathematical and statistical results using the proposed LS calculation equation. The proportion of the area of regions of each LS level to the total area of southern Anhui is determined using the GIS-based spatial statistical function and calculated as follows: high LS regions account for $21.3 \%$; relatively high LS regions account for $20.6 \%$; moderate LS regions account for $20.1 \%$; relatively low LS regions account for $11.7 \%$; and low LS regions account for $26.3 \%$, as shown in Figure 9.

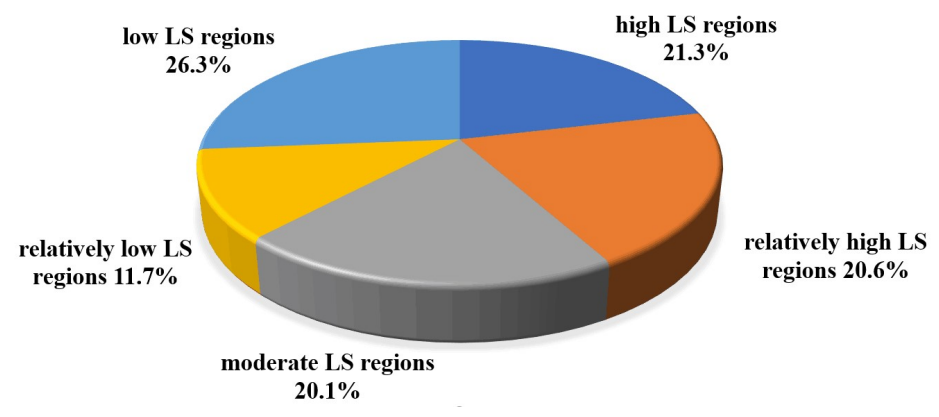

Figure 9. The proportion of the area of regions of each LS level to the total area of southern Anhui.

This study shows that the LS assessment model based on GIS spatial analysis and the AHP-weighted information content method can be satisfactorily applied to the LS assessment of southern Anhui, and it shows that the model and the method are practical and effective. 
Author Contributions: Handong He designed the research flow and wrote the manuscript. Di Hu contributed significantly to the conception of the study and constructive discussion. Qun Sun; Lei Zhu; Yanrong Liu performed the data analysis of the study. All authors read and approved the final manuscript.

Funding: National Natural Science Foundations of China; The Key Project of Natural Science Foundation of the Anhui Higher Education Institutions; National Undergraduate Innovation and Entrepreneurship Training Program: (No. 41601412, 41771421); (No. KJ2016A222); (No. 2019084).

Acknowledgments: This work is supported by the National Natural Science Foundation of China (No. 41601412, 41771421), the Key Project of the Natural Science Foundation of the Anhui Higher Education Institutions (No. KJ2016A222) and by the National Undergraduate Innovation and Entrepreneurship Training Program (No. 2019084). We would like to express our sincere thanks to the anonymous reviewers and editors for their valuable comments and suggestions for this paper.

Conflicts of Interest: The authors declare that they have no conflict of interest.

\section{References}

1. Guzzetti, F.; Mondini, A.C.; Cardinali, M.; Fiorucci, F.; Santangelo, M.; Chang, K.T. Landslide inventory maps: New tools for an old problem. Earth-Sci. Rev. 2012, 112, 42-66. [CrossRef]

2. Clerici, A.; Perego, S.; Tellini, C. A procedure for landslide susceptibility zonation by the conditional analysis method. Geomorphology 2002, 48, 349-364. [CrossRef]

3. Bunce, C.M.; Cruden, D.M.; Morgenstern, N.R. Assessment of the hazard from rock fall on a highway. Can. Geotech. J. 1997, 34, 344-356. [CrossRef]

4. Yamagishi, H. Integrated Disaster Prevention Maps and Landslide Hazard Maps using GIS: Examples of Shikoku and Central America Honduras. J. Jpn. Landslide Soc. 2014, 51, 24-29. [CrossRef]

5. Yamagishi, H. GIS Landslide: Identification and Mapping of Landslides; Springer: Tokyo, Japan, 2017.

6. Yamagishi, H.; Doshida, S.; Pimiento, E. GIS Analysis of Heavy-Rainfall Induced Shallow Landslides in Japan. In Landslide Science and Practice; Springer: Berlin, Germany, 2013.

7. Froude, M.J.; Petley, D.N. Global fatal landslide occurrence from 2004 to 2016. Nat. Hazards Earth Syst. Sci. 2018, 18, 2161-2181. [CrossRef]

8. Westen, C.J.V.; Asch, T.W.J.V.; Soeters, R. Landslide hazard and risk zonation-Why is it still so difficult? Bull. Eng. Geol. Environ. 2006, 65, 167-184. [CrossRef]

9. Metternicht, G.; Hurni, L.; Gogu, R. Remote sensing of landslides: An analysis of the potential contribution to geo-spatial systems for hazard assessment in mountainous environments. Remote Sens. Environ. 2005, 98, 284-303. [CrossRef]

10. Westen, C.J.V.; Castellanos, E.; Kuriakose, S.L. Spatial data for landslide susceptibility, hazard, and vulnerability assessment: An overview. Eng. Geol. 2008, 102, 112-131. [CrossRef]

11. Hou, W.; Lu, X.; Wu, P.; Xue, A.; Li, L. An integrated approach for monitoring and information management of the Guanling Landslide (China). ISPRS Int. J. Geo-Inf. 2017, 6, 79. [CrossRef]

12. Fell, R.; Corominas, J.; Bonnard, C.; Cascini, L.; Leroi, E.; Savage, W.Z. Guidelines for landslide susceptibility, hazard and risk zoning for land use planning. Eng. Geol. 2007, 102, 85-98. [CrossRef]

13. Chalkias, C.; Ferentinou, M.; Polykretis, C. GIS supported landslide susceptibility modeling at regional scale: An expert-based fuzzy weighting method. ISPRS Int. J. Geo-Inf 2014, 3, 523-539. [CrossRef]

14. Deng, X.; Li, L.; Tan, Y. Validation of spatial prediction models for landslide susceptibility mapping by considering structural similarity. ISPRS Int. J. Geo-Inf. 2017, 6, 103. [CrossRef]

15. Eeckhaut, M.V.D.; Poesen, J.; Verstraeten, G.; Vanacker, V.; Moeyersons, J.; Nyssen, J. The effectiveness of hillshade maps and expert knowledge in mapping old deep-seated landslides. Geomorphology 2005, 67, 351-363. [CrossRef]

16. Zhu, A.X.; Wang, R.; Qiao, J.; Qin, C.Z.; Chen, Y.; Liu, J. An expert knowledge-based approach to landslide susceptibility mapping using GIS and fuzzy logic. Geomorphology 2014, 214, 128-138. [CrossRef]

17. Bai, S.; Lu, G.; Wang, J. GIS-based rare events logistic regression for landslide-susceptibility mapping of Lianyungang, China. Environ. Environ. Earth Sci. 2010, 62, 139-149. [CrossRef] 
18. Yilmaz, I. Landslide susceptibility mapping using frequency ratio, logistic regression, artificial neural networks and their comparison: A case study from Kat landslides (Tokat-Turkey). Comput. Geosci. 2009, 35, 1125-1138. [CrossRef]

19. Liao, Q.L.; Li, X.; Lee, S.; Dong, Y.H. Occurrence, geology and geomorphy characteristics and origin of qianjiangping landslide in three gorges reservoir area and study on ancient landslide criterion. Chin. J. Rock Mech. Eng. 2005, 24, 3146-3153.

20. Pourghasemi, H.R.; Mohammady, M.; Pradhan, B. Landslide susceptibility mapping using index of entropy and conditional probability models in gis: Safarood basin, Iran. Catena 2012, 97, 71-84. [CrossRef]

21. Vahidnia, M.H.; Alesheikh, A.A.; Alimohammadi, A.; Hosseinali, F. A gis-based neuro-fuzzy procedure for integrating knowledge and data in landslide susceptibility mapping. Comput. Geosci. 2010, 36, 1101-1114. [CrossRef]

22. Akgun, A.; Sezer, E.A.; Nefeslioglu, H.A.; Gokceoglu, C.; Pradhan, B. An easy-to-use MATLAB program (MamLand) for the assessment of landslide susceptibility using a Mamdani fuzzy algorithm. Comput. Geosci. 2012, 38, 23-34. [CrossRef]

23. Tien Bui, D.; Pradhan, B.; Lofman, O.; Revhaug, I.; Dick, O.B. Spatial prediction of landslide hazards in Hoa Binh province (Vietnam): A comparative assessment of the efficacy of evidential belief functions and fuzzy logic models. Catena 2012, 96, 28-40. [CrossRef]

24. Yoshimatsu, H.; Abe, S. A review of landslide hazards in Japan and assessment of their susceptibility using an analytical hierarchic process (ahp) method. Landslides 2006, 3, 149-158. [CrossRef]

25. Kayastha, P.; Dhital, M.R.; De Smedt, F. Application of the analytical hierarchy process (ahp) for landslide susceptibility mapping: A case study from the Tinau watershed, west Nepal. Comput. Geosci. 2013, 52, 398-408. [CrossRef]

26. Hasekioğullari, G.D.; Ercanoglu, M. A new approach to use AHP in landslide susceptibility mapping: A case study at Yenice (Karabuk, NW Turkey). Nat. Hazards 2012, 63, 1157-1179. [CrossRef]

27. Bathrellos, G.D.; Skilodimou, H.D.; Chousianitis, K.; Youssef, A.M.; Pradhan, B. Suitability estimation for urban development using multi-hazard assessment map. Sci. Total Environ. 2017, 575, 119-134. [CrossRef] [PubMed]

28. Skilodimou, H.D.; Bathrellos, G.D.; Chousianitis, K.; Youssef, A.M.; Pradhan, B. Multi-hazard assessment modeling via multi-criteria analysis and GIS: A case study. Environ. Earth Sci. 2019, 78, 47. [CrossRef]

29. Rozos, D.; Bathrellos, G.D.; Skilodimou, H.D. Comparison of the implementation of Rock Engineering System (RES) and Analytic Hierarchy Process (AHP) methods, based on landslide susceptibility maps, compiled in GIS environment. A case study from the Eastern Achaia County of Peloponnesus, Greece. Environ. Earth Sci. 2011, 63, 49-63. [CrossRef]

30. Pradhan, B.; Lee, S. Landslide susceptibility assessment and factor effect analysis: Backpropagation artificial neural networks and their comparison with frequency ratio and bivariate logistic regression modelling. Environ. Model. Softw. 2010, 25, 747-759. [CrossRef]

31. Lee, S.; Talib, J.A. Probabilistic landslide susceptibility and factor effect analysis. Environ. Geol. 2005, 47, 982-990. [CrossRef]

32. Gao, K.; Cui, P.; Zhao, C.; Wei, F. Landslide hazard evaluation of wanzhou based on gis information value method in the three gorges reservoir. Chin. J. Rock Mech. Eng. 2006, 25, 991-996.

33. Che, V.B.; Kervyn, M.; Suh, C.E.; Fontijn, K.; Ernst, G.G.J.; Marmol, M.A.D. Landslide susceptibility assessment in limbe (SW Cameroon): A field calibrated seed cell and information value method. Catena 2012, 92, 83-98. [CrossRef]

34. Wang, J.; Yin, K.; Xiao, L. Landslide susceptibility assessment based on gis and weighted information value: A case study of wanzhou district, three gorges reservoir. Chin. J. Rock Mech. Eng. 2014, 33, 797-808.

35. Hong, H.; Ilia, I.; Tsangaratos, P.; Wei, C.; Chong, X. A hybrid fuzzy weight of evidence method in landslide susceptibility analysis on the Wuyuan area, China. Geomorphology 2017, 290, 1-16. [CrossRef]

36. Wang, Z.W.; Li, D.-Y.; Wang, X.G. Zonation of landslide hazards based on weights of evidence model. Chin. J. Geotech. Eng. 2007, 29, 1268-1273. 
37. Ayalew, L.; Yamagishi, H. The application of gis-based logistic regression for landslide susceptibility mapping in the kakuda-yahiko mountains, central Japan. Geomorphology 2005, 65, 15-31. [CrossRef]

38. Gorsevski, P.V.; Gessler, P.E.; Foltz, R.B.; Elliot, W.J. Spatial prediction of landslide hazard using logistic regression and roc analysis. Trans. GIS 2010, 10, 395-415. [CrossRef]

39. Akcay, O. Landslide fissure inference assessment by ANFIS and logistic regression using UAS-based photogrammetry. ISPRS Int. J. Geo-Inf. 2015, 4, 2131-2158. [CrossRef]

40. Kayastha, P.; Dhital, M.R.; Smedt, F. Evaluation of the consistency of landslide susceptibility mapping: A case study from the kankai watershed in east Nepal. Landslides 2013, 10, 785-799. [CrossRef]

41. Felicísimo, Á.M. Mapping landslide susceptibility with logistic regression, multiple adaptive regression splines, classification and regression trees, and maximum entropy methods: A comparative study. Landslides 2013, 10, 175-189. [CrossRef]

42. Jiang, W.; Rao, P.; Cao, R.; Tang, Z.; Chen, K. Comparative evaluation of geological disaster susceptibility using multi-regression methods and spatial accuracy validation. J. Geogr. Sci. 2017, 27, 439-462. [CrossRef]

43. Youssef, A.M.; Pourghasemi, H.R.; Pourtaghi, Z.S.; Al-Katheeri, M.M. Landslide susceptibility mapping using random forest, boosted regression tree, classification and regression tree, and general linear models and comparison of their performance at Wadi Tayyah Basin, Asir Region, Saudi Arabia. Landslides 2016, 13, 839-856. [CrossRef]

44. Genuer, R.; Poggi, J.M.; Tuleau-Malot, C. Variable selection using Random Forests. Pattern Recognit. Lett. 2010, 31, 2225-2236. [CrossRef]

45. Hong, H.; Pourghasemi, H.R.; Pourtaghi, Z.S. Landslide susceptibility assessment in Lianhua County (China): A comparison between a random forest data mining technique and bivariate and multivariate statistical models. Geomorphology 2016, 259, 105-118. [CrossRef]

46. Zhang, M.; Liu, J. Controlling factors of loess landslides in western China. Environ. Earth Sci. 2010, 59, 1671-1680. [CrossRef]

47. Wang, Y.; Lin, Q.; Shi, P. Spatial pattern and influencing factors of casualty events caused by landslides. Acta Geogr. Sin. 2017, 72, 906-917.

48. Bui, D.T.; Pradhan, B.; Lofman, O. Landslide susceptibility assessment in the Hoa Binh province of Vietnam: A comparison of the Levenberg-Marquardt and Bayesian regularized neural networks. Geomorphology 2012, 171, 12-29.

49. Yamagishi, H.; Iwahashi, J. Comparison between the two triggered landslides in Mid-Niigata, Japan by July 13 heavy rainfall and October 23 intensive earthquakes in 2004. Landslides 2007, 4, 389-397. [CrossRef]

50. Reichenbach, P.; Rossi, M.; Malamud, B.D.; Mihir, M.; Guzzetti, F. A review of statistically-based landslide susceptibility models. Earth-Sci. Rev. 2018, 180, 60-91. [CrossRef]

51. Pradhan, B.A. Comparative study on the predictive ability of the decision tree, support vector machine and neuro-fuzzy models in landslide susceptibility mapping using GIS. Comput. Geosci. 2013, 51, 350-365. [CrossRef]

52. Lan, H.X. Study on GIS-aided model for analysis of landslide hazard. J. Eng. Geol. 2002, 12, 4139-4181.

53. Tsangaratos, P.; Ilia, I.; Hong, H.; Chen, W.; Xu, C. Applying information theory and GIS-based quantitative methods to produce landslide susceptibility maps in Nancheng County, China. Landslides 2016, 14, 1091-1111. [CrossRef]

54. Devkota, K.C.; Regmi, A.D.; Pourghasemi, H.R. Landslide susceptibility mapping using certainty factor, index of entropy and logistic regression models in GIS and their comparison at Mugling-Narayanghat road section in Nepal Himalaya. Nat. Hazards 2013, 65, 135-165. [CrossRef]

55. Ba, Q.Q.; Chen, Y.M.; Deng, S.S.; Wu, Q.J.; Yang, J.X.; Zhang, J.Y. An improved information value model based on gray clustering for landslide susceptibility mapping. ISPRS Int. J. Geo-Inf. 2017, 6, 18. [CrossRef]

56. Feizizadeh, B.; Roodposhti, M.S.; Jankowski, P.; Blaschke, T. A GIS-based extended fuzzy multi-criteria evaluation for landslide susceptibility mapping. Comput. Geosci. 2014, 73, 208-221. [CrossRef] [PubMed]

57. Nefeslioglu, H.A.; Sezer, E.A.; Gokceoglu, C.; Ayas, Z. A modified analytical hierarchy process (M-AHP) approach for decision support systems in natural hazard assessments. Comput. Geosci. 2013, 59, 1-8. [CrossRef]

58. Chhetri, S.; Kayastha, P. Manifestation of an analytic hierarchy process (AHP) model on fire potentialzonation mapping in Kathmandu Metropolitan City, Nepal. ISPRS Int. J. Geo-Inf. 2015, 4, 400-417. [CrossRef] 
59. Carrara, A.; Cardinali, M.; Detti, R.; Guzzetti, F.; Pasqui, V.; Reichenbach, P. GIS techniques and statistical models in evaluating landslide hazard. Earth Surf. Process. Landf. 2010, 16, 427-445. [CrossRef]

60. Wang, F.; Xu, P.; Wang, C.; Wang, N.; Jiang, N. Application of a gis-based slope unit method for landslide susceptibility mapping along the Longzi river, southeastern Tibetan plateau, China. ISPRS Int. J. Geo-Inf. 2017, 6, 172. [CrossRef] 